\title{
Balneotherapy in Kangal hot spring with fish
}

\section{Kangall Balık\|lı Kaplıca'sında Ballneoterapi}

\author{
Sedat Özçelik ${ }^{1}$, *Sibel Berksoy Hayta ${ }^{1}$ \\ ${ }^{1}$ Department of Dermatology, Cumhuriyet University School of Medicine, Sivas, Turkey. \\ Corresponding author: Dr. Sibel Berksoy Hayta, Dermatoloji Anabilim Dalı, Cumhuriyet Üniversitesi Tıp Fakültesi, TR \\ 58140, Sivas, Türkiye. \\ E-mail: drberksoy@gmail.com \\ Received/Accepted: September 10, 2015/September 10, 2015 \\ Conflict of interest: There is not a conflict of interest.
}

\section{SUMMARY}

Balneotherapy, although not a well-established dermatological treatment, is thought to have therapeutic properties for psoriasis and is used as an alternative treatment modality throughout the world. Balneotherapy refers to immersion in baths or pools of thermomineral water. This treatment offers a natural, multifactorial, complementary, and nontoxic alternative to the traditional pharmacologic treatments of psoriasis. The major dermatologic diseases that are frequently treated by balneotherapy with a high rate of success are psoriasis and atopic dermatitis. Although a majority of clinical studies have used hypertonic Dead Sea water combined with phototherapy, Kangal Hot Spring is an important balneotherapy center in Turkey.

Keywords: Balneotherapy, psoriasis, Kangal Hot Spring

\section{ÖZET}

Balneoterapi, iyi tanımlanmış bir dermatolojik tedavi olmamasına rağmen psoriasis tedavisi için terapötik özeliklere sahiptir ve tüm dünyada alternatif tedavi seçeneği olarak kullanılır. Balneoterapi termomineralli banyo ya da havuzlarda kalarak tedavi olmay1 ifade etmektedir. Bu tedavi psoriasisin geleneksel farmakolojik tedavilerine karșı doğal, multifaktöriyel, komplemanter ve nontoksik bir alternatif sunmaktadır. Yüksek oranda başarıla birlikte balneoterapiyle tedavi edilebilen major dermatolojik hastalıklar psoriasis ve atopik dermatittir. Klinik çalışmaların çoğu Ölü Deniz' de yapılmakla birlikte Kangal Kaplıcası Türkiye'de önemli bir balneoterapi merkezidir. Anahtar sözcükler: Balneoterapi, psoriasis, Kangal kaplıcası

\section{INTRODUCTION}

Climatotherapy comprises alternative treatment methods employing the healing capacities of natural resources, including air, temperature, humidity, barometric pressure and light. Sea and spa water and products have been used for their healing, curative properties for thousands of years. Water-based treatments have been further specified resulting in novel terms such as balneotherapy, spa therapy, thalassotherapy, etc. The exact meaning of these terms is often controversial or overlapping ${ }^{1}$.

Balneotherapy is referred to as an alternative therapeutic method based on the use of thermomineral waters including bathing ${ }^{1,2}$. Mineral waters are natural solutions formed under specific geologic conditions and characterized by a "chemico-physical dynamism." They originate in springs, are bacteriologically pure, and have a therapeutic potential. Mineral waters may be classified in many ways according to their distinctive chemical and physical elements, such as temperature, molecular concentration, chemical composition, and mechanisms of therapeutic action. The composition and physical properties of various spa waters vary. They are salty, sulfurous, bicarbonated, sulfated, carbonic, arsenical, and ferruginous on the basis of their chem- 
ical content. They are also classified as being hypotonic, isotonic, or hypertonic. Spring water may also be radioactive. The waters used to treat dermatologic disorders have varying chemical and physical properties, but they are generally rich in sulfur, hydrogen sulfide, and sulfates ${ }^{3}$. Balneotherapy is widely used for the treatment of inflammatory skin diseases, such as psoriasis, atopic dermatitis, rosacea, seborrheic dermatitis, vitiligo and others ${ }^{46}$.

Psoriasis has a strong genetic basis, and treatment for psoriasis is aimed at inducing and maintaining remission. Therefore, the safety of long-term therapy is very important in the treatment of psoriasis. Conventional pharmacologic treatments, including methotrexate, acitretin, cyclosporine, and topical corticosteroids, can be used for limited durations due to their cumulative toxicity and potential side effects ${ }^{2}$. Many patients with psoriasis request alternative therapies and perceive them as helpful. One of the promising alternative therapies for psoriasis is balneotherapy. This treatment offers a natural, multifactorial, complementary, nontoxic alternative to the traditional pharmacologic treatments of psoriasis and has almost no adverse effects during and after treatment ${ }^{2,4,7,8}$.

Balneotherapy with hypotonic mineral water has been shown to improve psoriasis without additional treatment modalities ${ }^{2}$. The efficacy of spa therapy for inflammatory skin diseases and the mechanisms are only partly understood, and presumably incorporate chemical, thermal, mechanical and immunomodulatory effects, 5 . The chemical components of this thermal water, including sulfur, magnesium, and selenium, are thought to have beneficial effects on the skin. Heat may also have an antiinflammatory effect. Thermal stimulation causes vasodilatation, enhanced blood circulation, and decreased blood pressure. The moisturizing effect of bathing on the stratum cornea and the desquamation of dead keratinocytes can be beneficial to the skin $^{2}$. In addition, the psychological effects of balneotherapy cannot be overlooked. The acceptance of thermal balneotherapy by patients is further increased by the fact that it is performed in pleasant places, far from every-day stressing events and in a setting that favors dialogue and contact with many other people suffering of the same disease ${ }^{2,7}$. Balneotherapy is generally considered as safe therapeutic method. However, a number of contraindications for administering this treatment exist such as acute infection, active visceral tuberculosis, poorly controlled arterial hypertension, cardiac arrhythmias, and neoplastic diseases ${ }^{1}$.

Examples of unique places for water-based therapy are the Kangal hot spring in Turkey, the Dead Sea in Israel, and the Blue Lagoon in Iceland $d^{9,10}$.

Kangal Fishy Health Spa is located in Kangal district of Sivas. There are a number of spas in the area of Sivas. It has vastly been visited since Roman times. The spa named as Is1l Çermik (hot spring) in the documents is located within the city centre. It takes place in Seljukian documents dating back to 1333 and, since then, it has been used for the treatment of arthritis and skin diseases ${ }^{11}$.

Sivas became as one of the leading health centers of Anatolia in the Middle Ages. There were two health centers (dar alShifa) in that period which corresponds to contemporary Medical School: One of them is called as Izzeddin Kaykavus the I Health Centre (founded in 1217) and located in the city centre of Sivas whilst the second one took place in the East, $180 \mathrm{~km}$ away from the city centre, and was named as Divrigi Melike Turan Melek Health Centre (founded in 1228). Water was used a mean of treatment in both health centers $^{12}$.

Today Kangal Fishy Health Spa takes place in between of these two health centers and it was used for drinking and cleaning purposes by local people in around 1850 s. According to a legend, upon being noticed that it treats skin diseases in people and animals the spring happened to be an important centre for the treatment of skin diseases. According to another legend it is narrated that the spa began to be used by the local people after it was observed that it cured shepherds' skin diseases in their legs when they were walking in the water. In addition to the skin diseases, at that time, arthritis, gynecological diseases, and 
psychiatric ailments were also treated there.

Kangal became a municipality of Sivas in 1902. The local city council, which was appointed in 1942, started building treatment pools. Since the Kangal Fishy Health Spa was publicized in the media in around 1980s it has been drawing attention from outside Sivas. The first scientific publication regarding the spa appeared in $1983^{13}$.

A symposium named Kangal Fishy Health Spa-Psoriasis Treatment was organized in 1993 by the author of this article ${ }^{14}$. In connection with its such an academic dimension, it was officially recognized as a treatment centre by the Ministry of Health of Turkey Republic in 2004.

Kangal Fishy Health Spa is located $14 \mathrm{~km}$ north of Kangal, a small town in the vicinity of Sivas. The altitude of spa is approximately 1600 meters. The spa consists of 5 pools with a total capacity of $2001 \mathrm{t} / \mathrm{sec}$. The mean water temperature is $35^{\circ} \mathrm{C}$, the mean oxygen value is $2.9 \mathrm{ppm}$, and the $\mathrm{pH}$ value is 7.8 .

This spa water contains many elements, and most important of them is selenium $(1.3 \mathrm{mg} / \mathrm{L})$. Chemical analysis of the spa water is shown in tables 1 and $2^{15}$.

Table 1: Cationic ingredients of spa.

\begin{tabular}{l|ll} 
Chemicals & $\mathbf{m E q} / \mathbf{L}$ & $\mathbf{~ m g} / \mathbf{L}$ \\
\hline Sodium $(\mathrm{Na}+)$ & 0.17 & 3.91 \\
Potassium $(\mathrm{K}+)$ & 0.03 & 1.09 \\
Lithium $(\mathrm{Li}+)$ & - & - \\
Ammonia $(\mathrm{NH}+)$ & 0.006 & 0.11 \\
Magnesium $(\mathrm{Mg}++)$ & 3.75 & 44.95 \\
Calcium $(\mathrm{Ca}+)$ & 2.71 & 54.22 \\
Iron $(\mathrm{Fe}++, \mathrm{Fe}+++)$ & 0.006 & 0.175 \\
Zinc $(\mathrm{Zn++})$ & 0.0006 & 0.02 \\
Aluminum $(\mathrm{Al}+++)$ & 0.045 & 0.005 \\
Manganese $(\mathrm{Mn}+)$ & 0.004 & 0.1 \\
Copper $(\mathrm{Cu}++)$ & 0.0008 & 0.027 \\
Chrome $(\mathrm{Cr})$ & 10.006 & 0.1
\end{tabular}

Table 2: Anionic ingredients of spa.

\begin{tabular}{l|ll}
\hline Chemicals & $\mathbf{m E q} / \mathbf{L}$ & $\mathbf{~ m g / L}$ \\
\hline Bicarbonate (HCO-4) & 4.96 & 302.4 \\
Carbonate (CO-) & - & - \\
Chloride (Cal-) & 0.675 & 23.92 \\
Iodine (I-) & - & - \\
Bromide (Br-) & 0.0084 & 0.675 \\
Flouride (F-) & 0.014 & 0.27 \\
Sulphate (SO4-) & 0.958 & 46.00 \\
Nitrate (N03) & 0.053 & 3.32 \\
\hline
\end{tabular}

What makes the Kangal Fishy Health Spa unique among the other spas in the world is the fish living in the spa. The fish increase the effectiveness of the spa. Two different types of fish live in the pools. Both of them are members of the Cyprinidae family. The first type of fish is Cyprinion macrostomus HECKEL, the second type is Gara rufa obtusa HECKEL. Although these fish have an ordinary morphological structure, the length of their bodies is shorter $(4-14 \mathrm{~cm})$ than other members of the same family, which live in the rivers of this area. Despite the high temperature of water, these fish live in the pools, settling to hot water. Because of the scarcity of natural food sources in the pools, human skin is an attractive and easy food source for these fish ${ }^{13,15}$.

Every year, five thousands psoriatic patients on average visit the spa seeking treatment for their diseases. The majority of the visitors consist patients of psoriasis diseases. Other skin diseases include atopic eczema, eczema, vitiligo, lichen, and diseases belong to ichthyosis family ${ }^{16}$.

In Kangal Fishy Health Spa, whilst the patients with psoriasis vulgaris and arthropathic psoriasis are treated in general, patients with erythrodermic or pustular psoriasis and those with a history of photosensitive disease are not treated. The patients are suggested not to use photo sensitizer's drugs and foods. During the treatment period topical or systemic drugs are not allowed to use, except for moisturizers. In addition, during treatment the patients are asked to drink spa water ad libitum.

The patients get into the pool twice a day, once in the morning and once in the afternoon. The period of staying in the pools is approximately 7.4 hours during which the patients also receive natural UV light in the pools. Between the hours of 11:00 and 14:00, they are told not to be subjected to direct UV light. In the pools, 10 to 15 people can take the treatment at the same time. Traditionally, the recommended time of treatment in the spa is 21 days. The average period of staying in the spa is 11 days ${ }^{17}$.

On the first day of the treatment, the squamae on the patients are totally cleaned by the fish. The cleaning process of squa- 
ma continues during the treatment process, and at the end the patients are left with no squamae. During the cleaning process of the squamae, on the psoriatic plaque, superficial exulceration and slight hemorrhage may be seen. On the proceeding days, these gradually decrease and finally disappear. Due to these superficial exulcerations, the Koebner phenomenon does not occur. Furthermore, it can be said that the Reverse Koebner phenomenon takes role in the curing of these psoriatic plaques.

The continuous cleaning of the squamae by the fish and the hydration of skin in the pool increase the penetration of minerals through the epidermis. Especially, the penetration of selenium increases. Besides that, the penetration of other elements like magnesium, zinc increase and this takes role in the treatment.

Since the spa is at an altitude of 1600 meters, the doze of natural UV light increases. Hydration of the skin increases of UV effect $^{18}$. The continuous cleaning of the squamae by the fish and the hydration of the skin increases the effectiveness of the treatment. It can be said that the selenium present in the water prevents the carcinogenic effects of natural phototherapy.

The spa water is drinkable. People staying there maintain their water requirements from the spa as well as drinking that water for treatment purposes. The systemic intake of selenium and other minerals plays a role in the treatment. The selenium and other elements have antioxidant, antiproliferatif and immunmodulatory ${ }^{3,} 19$ effects on the skin.

The cleaning of the squamae on the first day effects the psychological situations of the patients in a positive way. The patients are being treated in the pools. The existence of 10 to 15 people in the same pool and the communication between them helps the treatment process. Also, the assumption made by some people that this is a holy spa improves the psychological situations of the patients who think that way. In addition to skin cure mentioned so far it is assumed that by staying in the Spa people get the opportunity to be away from daily stress and hassles and from other emotional tensions.

In a study ${ }^{20}$ conducted in our clinic, Brief Symptom Inventory (BSI) tests before and after treatment were evaluated. A decrease was observed in the points of global symptom index and submeasures of obsessivecompulsive somatization, interpersonal sensitivity, phobic anxiety, paranoid ideation, depression, hostility, statistical evaluation was significant. No change of BSI for anxiety was obtained after the treatment according to the results of initial. This study showed the patients' psychology affected positively.

The patients with psoriasis have dry skins. The continuous hydration decreases the some symptoms, including pruritus. Additionally, it can be said that with hydration the antigens and antigenic stimulation in the epidermis decreases ${ }^{21}$.

While the fish clean the squamae starting from the first day, superficial exulcerations occur. The beginning of curing in these plaques may be explained by Reverse Koebner phenomena. Water springs from the pools' bases; Jacuzzi effect is present although a little.

During the treatment process, no serious side effect is seen. On the patients with scalp psoriasis, irritation dependent otitis can develop, as a result of keeping their heads in the water continuously. Patients should use earplugs for prevent this adverse effect.

In our study conducted in this spa, the evaluations of the patients are being done with the PASI scoring method. The PASI scores that are being recorded with intervals of three days start to decrease immediately. While $57 \%$ of the patients recover completely at the end of 21 days treatment period, the decrease on the PASI scores of the remaining patients is over $80 \%$. It can be said that, as the period of staying in the spa increases, the PASI scores will decrease even more. In our study, the rate of patients being in remission for one or more years is $22.8 \%$. According to what is told by the patients, the remission length is longer as compared to any drug treatment (topical or conventional systemic treat- 
ments) $36.4 \%$ of the patients in the spa consist of those coming back to the spa for the second time or more. These patients come to the spa once a year and continue their treatments.

Kangal spa therapy was named ichtyotherapy by some author ${ }^{22,23}$. The treatment of Kangal Hot Spring with Fish (Kangal
Fishy Health Spa) should not be considered as ichthyotherapy. It is rather a method of balneotherapy-climatotherapy effectivity of which is accelerated and increased by the contribution of the fish. Some important factors seem to play a role in the treatment of psoriasis in the $\mathrm{spa}^{2426}$ (Table $3)$.

Table 3: Effectiveness of Kangal hot spring.

\begin{tabular}{|c|c|}
\hline Continuous decapitage of squams & ing of squams: Increa \\
\hline $\begin{array}{l}\text { The effects of selenium and other elements } \\
\text { in the drinking and bathing water. }\end{array}$ & $\begin{array}{l}\text { The selenium and other elements have antioxidant, antiprolifer- } \\
\text { ative and immunmodulatory effects on the skin diseases in two } \\
\text { ways: systemic effect (by drinking) and local effect (by pene- } \\
\text { trating into the skin). }\end{array}$ \\
\hline The effect & Natural phototherapy \\
\hline Group treatment and psychological effect & Positive psychological effects \\
\hline $\begin{array}{l}\text { Jacuzzi effect of the water on the cleaning } \\
\text { of squamae }\end{array}$ & Patient compliance \\
\hline The Reverse Koebner phenomenon & Positive physical effect \\
\hline
\end{tabular}

\section{REFERENCES}

1. Kazandjieva J, Grozdev I, Darlenski R, Tsankov N. Climatotherapy of psoriasis. Clin Dermatol 2008; 26: 477-85.

2. Lee YB, Lee JY, Lee HJ, Yun ST, Lee JT, Kim HJ, Yu DS, Woo SY, Kim JW. Immunomodulatory effects of balneotherapy with haeun-dae thermal water on imiquimod-induced psoriasis-like murine model. Ann Dermatol 2014; 26: 221-30.

3. Matz H, Orion E, Wolf R. Balneotherapy in dermatology. Dermatol Ther 2003; 16: 132-40.

4. Choi YJ, Lee HJ, Lee do H, Woo SY, Lee KH, Yun ST, Kim JM, Kim HJ, Kim JW. Therapeutic effects and immunomodulation of suanbo mineral water therapy in a murine model of atopic dermatitis. Ann Dermatol 2013; 25: 462-70.

5. Lee HP, Choi YJ, Cho KA, Woo SY, Yun ST, Lee JT, Kim HJ, Lee KH, Kim JW. Effect of Spa Spring Water on Cytokine Expression in Human Keratinocyte HaCaT Cells and on Differentiation of CD4 (+) T Cells. Ann Dermatol 2012; 24: 324-36.

6. Czarnowicki T, Harari M, Ruzicka $\mathrm{T}$, Ingber A. Dead Sea climato- therapy for vitiligo: a retrospective study of 436 patients. J Eur Acad Dermatol Venereol 2011; 25: 95963.

7. Farina $\mathrm{S}$, Gisondi $\mathrm{P}$, Zanoni $\mathrm{M}$, Pace M, Rizzoli L, Baldo E, Girolomoni G. Balneotherapy for atopic dermatitis in children at Comano spa in Trentino, Italy. J Dermatolog Treat 2011; 22: 36671.

8. Peroni A, Gisondi $\mathrm{P}$, Zanoni $\mathrm{M}$, Girolomoni G. Balneotherapy for chronic plaque psoriasis at Comano spa in Trentino, Italy. Dermatol Ther 2008;21: 31-8.

9. Eysteinsdóttir JH, Ólafsson $\mathrm{JH}$, Agnarsson BA, Lúðvíksson BR, Sigurgeirsson B. Psoriasis treatment: faster and long-standing results after bathing in geothermal seawater. A randomized trial of three UVB phototherapy regimens. Photodermatol Photoimmunol Photomed 2014; 30: 25-34.

10. Gambichler T, Demetriou C, Terras S, Bechara FG, Skrygan M. The impact of salt water soaks on biophysical and molecular parameters in psoriatic epidermis equivalents. Dermatology 2011; 223: 230-8.

11. Üçer M.Tıp. Tarihimizde Sivas. 
VIII. Türk Tip Tarihi KongresiSivas-Divriği 2004 Kongre Kitabı. Sar1 N, Erdemir AD ed. İstanbul, 2006; 240-258.

12. Başağoğlu İ. Bakır B. Anadolu Selçuklu Darüşşifalarında mimariyi etkileyen ögeler. VIII. Türk Tıp Tarihi Kongresi, Sivas-Divriği 2004 Kongre Kitabi. Sar1 N, Erdemir AD. İstanbul 2006; 137-41.

13. Timur M, Çolak A, Marufi M. Balıklı Kaplıca'daki balık türlerinin tanımı ve deri hastalıkları tedavisindeki etkilerinin araştırılmas1. AÜ Vet Fak Derg 1983; 30: 276-86.

14. Aydemir EA. Kangal Balıklı Kaplicas1 ve psoriasis. Türkderm 1993; 27: 143-4.

15. Özer Z, Akpınar MA, Akçay M. Kangal Balıklı Kaplıca'nın Bazı Kimyasal ve Biyolojik Özelliklerin Araştırılması. C.Ü.Fen Bilimleri Derg Ek Sayı 1987; 1-34.

16. Özçelik S, Polat HH, Yalçın AN. Kangal Balıklı Kaplica'da psoriasis tedavisi Şifaiye-Sivas 1994; 1: 1-6.

17. Özçelik S, Polat HH, Akyol M. Kangal Hot Spring with Fish and Psoriasis Treatment. J Dermatol 2000; 27: 386-90.

18. Boer J. The influence of mineral water solutions in phototherapy. Clin Dermatol 1996; 14: 665-73.

19. Staquet MJ, Navarro JP, Latourre F. In vitro effects of a spa water on the migratory and stimulatory capacities of human epidermal langerhans cells. Eur J Dermatol 1997; 7: 339-42.

20. Özçelik S, Akyol M, Cayır H. Assessment of depression and anxiety in psoriatic patients treated in Kangal Spa. V.Hungarıan-Turkish Balneological Symposium. Heviz, Hungary 2007; 7-10.

21. Bernstein JE. Dermatologic aspects of mineral water. Clin Dermatol 1996; 14: 567-9.

22. Grassberger M, Hoch W. Ichthyotherapy as Alternative Treatment for patients with psoriasis: A pilot Study. eCAM 2006; 3: 483-8.

23. Kazandjieva J, Grozdev I, Darlen- ski R. Climatotherapy of psoriasis. Clin Dermatol 2008; 26: 477-85.

24. Özçelik S, Akyol M. Psoriyasizde balneoterapi ve alternatif tedaviler. Türkiye Klinikleri Dahili Tip Bilimleri-Dermatoloji 2005; 1: 8994.

25. Özçelik S, Akyol M. Kangal spa with fish and psoriasis treatment. 33th Congres of The Internalional Society of Medical Hydrology Climatology Congres Book. Karagülle MZ, Dönmez A ed. İstanbul 2006: 76.

26. Özçelik S, Akyol M. PsoriasisKlimaterapi. Türkderm 2008; 42: 51-5. 